\title{
Bitter gourd little leaf disease associated to 'Candidatus Phytoplasma asteris'
}

\author{
Nang Kyu Kyu Win ${ }^{1,2}$, Young-Hwan Kim ${ }^{1}$ \& Hee-Young Jung ${ }^{1}$ \\ ${ }^{1}$ School of Applied Biosciences, College of Agriculture and Life Sciences, Kyungpook National University, Daegu 702-701, \\ Korea; ${ }^{2}$ Department of Plant Pathology, Yezin Agricultural University, Yezin, 05282, Myanmar
}

Author for correspondence: Hee-Young Jung, e-mail: heeyoung@knu.ac.kr

\begin{abstract}
Little leaf disease symptoms including dwarfed, thickened and puckered leaves and shortened internodes of bitter gourd (Momordica charantia L.) plants were observed in Meiktila, Myanmar 2012. The causal agent was detected by polymerase chain reaction using universal phytoplasma primers, and classified by sequencing of $16 \mathrm{~S}$ rRNA gene, ribosomal protein $(r p)$ gene and protein translocase subunit ( $\mathrm{sec} Y$ ) gene and RFLP analysis. The expected target phytoplasma DNA fragment of $1.8 \mathrm{kbp}$ was amplified from the bitter gourd little leaf (BitLL) diseased samples. The 16S rRNA gene sequence analysis of BitLL phytoplasma showed $99.7 \%$ to $99.9 \%$ identity with members of 'Candidatus Phytoplasma asteris' associated with sesame phyllody (SP), periwinkle phyllody (PeP) and periwinkle little leaf (PeLL) diseases in Myanmar. Moreover, $r p$ and $\sec Y$ gene sequences of the BitLL isolate were $99.7 \%$ to 100\%, and 99.9\% to 100\% identity among the SP, PeP and PeLL phytoplasma. However, putative restriction analysis revealed that the BitLL isolate missed one Mse I site on $r p$ gene sequence while other isolates had the same restriction sites. Phylogenetic analysis of the three genes confirmed that the phytoplasma belongs to the ' $\mathrm{Ca}$. P. asteris'. This is the first report of ' $\mathrm{Ca}$. P. asteris' infecting a member of the family Cucurbitaceae in Myanmar.
\end{abstract}

Key words: Cucurbitaceae, phylogenetic analysis, sequence analysis.

\section{INTRODUCTION}

Bitter gourd (Momordica charantia L.) is one of the most popular vegetables in Southeast Asia. It is annual tropical and subtropical vine of the family Cucurbitaceae along with cucumber, squash, watermelon and muskmelon (Palada \& Chang, 2003). It is also known as bitter melon, bitter squash and balsam pear, and widely cultivated in Asia and Africa and is regarded as a noxious weed in South America. Numerous medicinal uses have been documented or claimed such as stomachic, carminative and for diabetes treatment (Grover et al., 2002) and there are claims that it can also be used for prevention of breast cancer (Ray et al., 2010). In Myanmar, bitter gourd is widely grown in year round for its immature fruits and used as a vegetable. Several varieties of the bitter gourd are grown for local consumption, and use as a medicine to treat diabetes.

Little leaf symptoms were observed on bitter gourd plants in a commercial field at Meiktila in 2012. The leaves of infected vines were small, thickened, yellowish green and puckered and the internodes were thickened and shortened (Figure 1). Flowers of affected plants were reduced in size, did not fully open at maturity and finally withered within a few days. These symptoms seemed to be caused by a virus but the sole viral diseases known for bitter gourd are yellow mosaic diseases. Montano et al. (2000) reported a phytoplasma disease of bitter melon in Brazil.

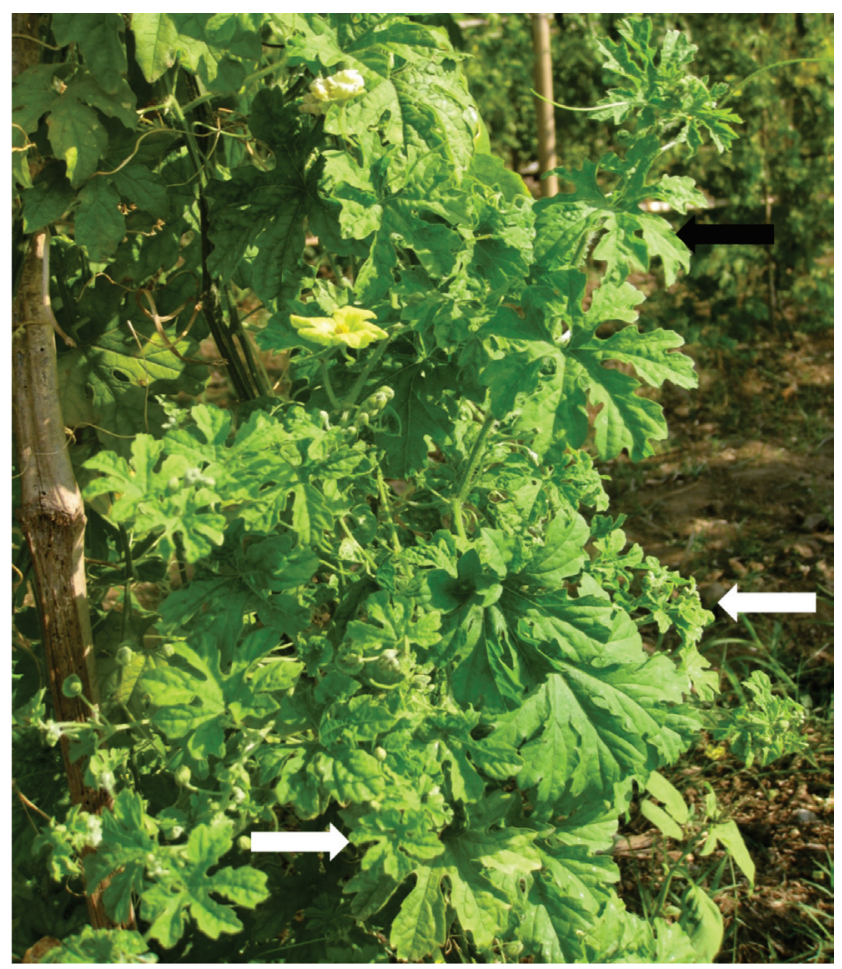

FIGURE 1 - Little leaf symptom on naturally infected bitter gourd plants exhibiting yellowish green, thickened, puckered leaves and internodes shortening (white arrow) compared to normal healthy vine (black arrow). 
Infected plants exhibited yellowing, reduction in size of leaves and witches' brooms and the associated phytoplasma belonged to X-disease phytoplasma subgroup 16SrIII-J. Another disease on $M$. charantia producing phyllody symptoms caused by aster yellows phytoplasma group in Thailand (Spoodee et al., 1999). Diseased bitter gourd plants observed in this study exhibited little leaf symptom. In Myanmar, plant diseases associated with phytoplasmas have been reported in a wide range of plant families (Win \& Jung, 2012) but there was no report of phytoplasma diseases for the Cucurbitaceae. Results of a study performed to clarify the etiology of the little leaf disease of bitter gourd in Myanmar are presented here.

\section{MATERIAL AND METHODS}

\section{Total DNA extraction and PCR amplification}

Samples of bitter gourd showing little leaf symptoms were collected from naturally infected bitter gourd plants grown in fields of the Segyi area near Meiktila Township, Myanmar in 2012 and taken to the laboratory. Total DNA was extracted from about $0.3 \mathrm{~g}$ leaf sample using cetyltrimethylammonium bromide buffer described by Namba et al. (1993). Total DNAs of other isolates used in this study were: Sesame phyllody (SP-YZ, AB558132), periwinkle little leaves (PeLL, AB646266), periwinkle phyllody (PeP-NS, AB646267) and periwinkle phyllody (PeP-YZ, AB646268) that were kept in storage at $-80^{\circ} \mathrm{C}$ at the Plant Pathology Laboratory at the Kyungpook National University, South Korea. These isolates belonged to ' $\mathrm{Ca}$. P. asteris' (Win et al., 2011; Win and Jung, 2012).

The DNA templates were used to detect phytoplasma by polymerase chain reaction (PCR) using universal primers SN910601/SN011119 that amplify about $1.8 \mathrm{kbp}$ DNA fragment including nearly full length of 16S rRNA gene, the spacer region and partial of 23S rRNA gene (Jung et al., 2003). The $r p$ gene was amplified by the primers $\mathrm{rp}(\mathrm{I}) \mathrm{F} 1 \mathrm{~A} /$ $\operatorname{rp}(\mathrm{I}) \mathrm{R} 1 \mathrm{~A}$ that amplify about $1.2 \mathrm{kbp}$ of the $r p$ operon that encompassed genes rpl22 and rps3 (Lee et al., 2004). The $\sec Y$ gene (about $1.4 \mathrm{kbp}$ ) was amplified by AYsecYF1/ AYsecYR1 (Lee et al., 2006).

The PCR products were analyzed by electrophoresis in $1 \%$ agarose gel stained with ethidium bromide and the DNA bands were viewed with an UV transilluminator.

\section{Sequencing and sequence identity analysis}

The PCR products of 16S rRNA, $r p$ and $\sec Y$ gene were purified with ExoSAP-IT (USB) and direct sequenced using the ABI 3730 XL DNA sequencer (SolGent) with the primers used in the PCR analysis. The 16S rRNA gene PCR products were sequenced with five primers $(350 \mathrm{~F}, 350 \mathrm{R}$, 520F, 520R and 788F) in order to get the full-length of the 16S rRNA gene including spacer region and partial of 23S rRNA gene sequence (Table 1). The $r p$ and $\sec Y$ genes were sequenced with the same primers used in the PCR analysis. The sequences were then assembled and edited
TABLE 1 - Primers used for sequencing of 16S rRNA gene.

\begin{tabular}{ll}
\hline \hline Primer & \multicolumn{1}{c}{ Sequence (5'-3') } \\
\hline $350 \mathrm{~F}$ & TAC GGG AGG CAG CAG \\
$350 \mathrm{R}$ & CTG CTG CCT CCC GTA G \\
$520 \mathrm{~F}$ & GTG CCA GCA GCC GCG G \\
$520 \mathrm{R}$ & ACC GCG GCT GCT GGC \\
$788 \mathrm{~F}$ & ATT AGA TAC CCT GGT A \\
\hline
\end{tabular}

using DNASTAR's lasergene software (DNASTAR) and consensus sequences were generated. The sequence identity between isolates was analyzed by using GENETYX-WIN 3.2 software (Genetyx Co.). Then, the sequences were deposited in GenBank database. The accession numbers are AB746131, AB746132 and AB746133 for 16S rRNA, $r p$ and $\sec Y$ gene sequence of the BitLL phytoplasma respectively. For $r p$ gene sequences of SP-YZ, PeLL and PeP-YZ isolates accession numbers are AB741638, $\mathrm{AB} 741640$ and $\mathrm{AB} 741642$ respectively, and for $\sec Y$ gene sequences of SP-YZ and PeLL accession numbers are $\mathrm{AB} 741639$ and $\mathrm{AB} 741641$ respectively.

\section{Restriction fragment length polymorphism (RFLP) analysis}

The 16S rRNA gene PCR products ( 1.8 kbp) were digested with Alu I, Mse I, Kpn I, Hae III, Rsa I and Taq I enzyme separately. The $r p$ and $\sec Y$ gene products were digested with Alu I, Mse I and Tsp 509I. The restriction products were then separated by electrophoresis through $8 \%$ polyacrylamide gel, stained in ethidium bromide, and visualized with a UV transilluminator. Putative restriction site maps were also generated for $r p$ gene sequences $(\sim 1.2$ kbp) by DNASTAR's Lasergene software.

\section{Phylogenetic analysis}

Phylogenetic relationship among the isolates of BitLL, SP-YZ, PeLL, PeP-NS and PeP-YZ and other phytoplasmas were analyzed based on $16 \mathrm{~S}$ rRNA, $r p$ and $\sec Y$ gene sequences. The $16 \mathrm{~S}$ rRNA gene sequences of aster yellows group phytoplasmas retrieved from GenBank database were aligned by using Clustal W. Stolbur (X76427), 'Ca. P. fragariae' (EU338446) and stolbur (GU004346) were used as the outgroup for $16 \mathrm{~S}$ rRNA, $r p$ and $\sec Y$ gene based analysis respectively. The trees were constructed by neighbor-joining method with the bootstrap analysis of 1,000 replicates and the trees were viewed by TREEVIEW (Page, 1996).

\section{RESULTS AND DISCUSSION}

The presence of a phytoplasma associated with bitter gourd bearing little leaf symptoms was confirmed by the amplified DNA fragment of the expected size ( $1.8 \mathrm{kbp})$ from the diseased leaves while no DNA fragment was amplified from the healthy leaves and the negative control. The PCR 
results confirmed that the little leaf disease of bitter gourd is associated with a phytoplasma.

Nearly full-length of 16S rRNA gene sequence including spacer region and partial of 23S rRNA gene of BitLL phytoplasma was $1,838 \mathrm{kbp}$ in length and operon heterogeneity was observed on nucleotide sequence data. BLAST analyses revealed that the BitLL phytoplasma has the highest similarity $(99.9 \%)$ with members of 'Candidatus Phytoplasma asteris'. The $r p$ and $\sec Y$ gene sequences of five isolates; BitLL, SP-YZ, PeLL, PeP-YZ and PeP-NS, were about $1.2 \mathrm{kbp}$ and $1.4 \mathrm{kbp}$ respectively. Percent homologies between five isolates of $16 \mathrm{~S}$ rRNA, $r p$ and $\sec Y$ gene sequences are presented in Table 2. BitLL, SP-YZ and PeLL isolates share 99.9\% identity, and $99.7 \%$ to $99.8 \%$ identity among three periwinkle isolates for 16S rRNA gene sequences. For $r p$ gene sequences, there is $99.7 \%$ to $100 \%$ identity among them, and $100 \%$ identity between SP-YZ, PeP-NS and PePYZ. The $\sec Y$ gene sequences had $100 \%$ identity among the isolate except BitLL that shared $99.9 \%$ identity with others. The sequence identity comparison showed that the BitLL isolate is close to the other four isolates for the three genes examined. The $\sec Y$ gene sequences of the isolates were more stable than $r p$ and 16S rRNA gene sequences.

The RFLP profiles were generated by restriction enzymes for the 16S rRNA gene PCR products $(\sim 1.8 \mathrm{kbp})$, $r p(1.2 \mathrm{kbp})$ and $\sec Y$ genes $(1.4 \mathrm{kbp})$ of five isolates (Figure 2 ). In figure $2 \mathrm{~A}$, the RFLP profiles analyzed by six enzymes were almost identical among five isolates although there were two additional fragments on Taq I enzyme between $1,000 \mathrm{bp}$ and $500 \mathrm{bp}$ for SP-YZ, PeLL, PeP-NS and PeP$\mathrm{YZ}$ isolates. The presence of additional fragments would be affected by operon heterogeneity. In RFLP profiles for $r p$ gene, the BitLL isolate differed from other isolates on Mse I site at about $80 \mathrm{bp}$ (Figure 2B). This difference was confirmed by generating putative restriction map for $r p$ gene sequences of five isolates. The BitLL isolate had one
Mse I site lacking between 300 and 350 bp. Except that, the five isolates had the same restriction sites. Similarly, the indistinguishable RFLP profiles were obtained for $\sec Y$ gene products of five isolates (Figure 2C).

Phylogenetic relationship derived from the $16 \mathrm{~S}$ rRNA, $r p$ and $\sec Y$ gene sequences was analyzed for the five isolates, BitLL, SP-YZ, PeLL, PeP-NS and PeP-YZ, and other members of ' $\mathrm{Ca}$. P. asteris' (Figure 3). The five Myanmar isolates had variation among 16S rRNA gene sequences (Figure 3A). Among them, $r p$ and $\sec Y$ gene sequences of the BitLL isolate differed from other four isolates (Figure 3B, C). All results indicate significant genetic variation among the five isolates of ' $\mathrm{Ca}$. P. asteris' from Myanmar. This was also observed for the BitLL phytoplasma.

Phytoplasma association with witches' broom disease of bitter gourd was first described in Taiwan where the phytoplasma was observed with an electron microscope (Chou et al., 1976). Later, a phyllody disease on bitter gourd caused by aster yellows phytoplasma was also reported and the agent was identified by RFLP analysis in Thailand (Spoodee et al., 1999). Based on the previous (Montano et al., 2000) and this study, the bitter gourd plants can be attacked by two phytoplasmas: ' $\mathrm{Ca}$. P. pruni' (x-disease phytoplama group) and ' $\mathrm{Ca}$. P. asteris'. Few plants belonging to the Cucurbitaceae have been previously described as hosts for ' $\mathrm{Ca}$. P. asteris' namely: Cucumis sativus L. in Taiwan (GenBank data, Wang et al., 2008), Luffa cylindrica M. Roem. in India (Kumar et al., 2010) and Sechium edule (Jacq.) Swartz in Costa Rica (GenBank data, Saborio-R et al., 2005). This study reports bitter gourd as an additional cucurbitaceous hosts for ' $\mathrm{Ca}$. P. asteris'. and it represents an addition to the list of plant hosts for phytoplasmas in Myanmar (Win \& Jung, 2012). This is also the first time a molecular characterization supporting the record of ' $\mathrm{Ca}$. P. asteris' association with little leaf of bitter gourd is provided.

TABLE 2 - Percent similarity (\%) of $16 \mathrm{~S}$ rRNA, $r p$ and $\sec Y$ gene sequences among the ' $\mathrm{Ca}$. P. asteris' isolates from bitter gourd, sesame and periwinkle plants.

\begin{tabular}{|c|c|c|c|c|c|c|c|c|c|c|c|c|c|c|c|}
\hline & \multicolumn{5}{|c|}{ 16S rRNA gene } & \multicolumn{5}{|c|}{$r p$ gene } & \multicolumn{5}{|c|}{ sec $Y$ gene } \\
\hline & $\stackrel{ت}{. 尹}$ & $\begin{array}{l}N \\
\stackrel{1}{1} \\
\stackrel{1}{\infty}\end{array}$ & $\begin{array}{l}\exists \\
\stackrel{0}{0}\end{array}$ & $\begin{array}{l}n_{1} \\
z_{1} \\
0 \\
2\end{array}$ & $\begin{array}{l}N \\
\overline{1} \\
0 \\
0\end{array}$ & $\stackrel{ت}{.}$ & \begin{tabular}{l}
$N$ \\
\multirow{1}{1}{} \\
$\tilde{n}^{2}$
\end{tabular} & ت. & $\begin{array}{l}n \\
Z \\
1 \\
0 \\
0\end{array}$ & $\begin{array}{l}N \\
\text { D } \\
0 \\
0\end{array}$ & 惹 & $\begin{array}{l}N \\
\stackrel{1}{1} \\
\stackrel{1}{\infty}\end{array}$ & $\stackrel{3}{0}$ & $\begin{array}{l}\infty \\
Z_{1} \\
0 \\
0\end{array}$ & $\begin{array}{l}N \\
0 \\
0 \\
0\end{array}$ \\
\hline $\mathrm{BitLL}^{1}$ & 100 & 99.9 & 99.9 & 99.7 & 99.8 & 100 & 99.8 & 99.7 & 99.8 & 99.8 & 100 & 99.9 & 99.9 & 99.9 & 99.9 \\
\hline SP-YZ & & 100 & 99.9 & 99.8 & 99.7 & & 100 & 99.9 & 100 & 100 & & 100 & 100 & 100 & 100 \\
\hline PeLL & & & 100 & 99.8 & 99.8 & & & 100 & 99.9 & 99.9 & & & 100 & 100 & 100 \\
\hline PeP-NS & & & & 100 & 99.7 & & & & 100 & 100 & & & & 100 & 100 \\
\hline PeP-YZ & & & & & 100 & & & & & 100 & & & & & 100 \\
\hline
\end{tabular}

${ }^{1}$ BitLL, bitter gourd little leave; SP-YZ, sesame phyllody-Yezin; PeLL, periwinkle little leave; PeP-NS, periwinkle phyllody-Ngwesaung; PeP-YZ, periwinkle phyllody-Yezin 

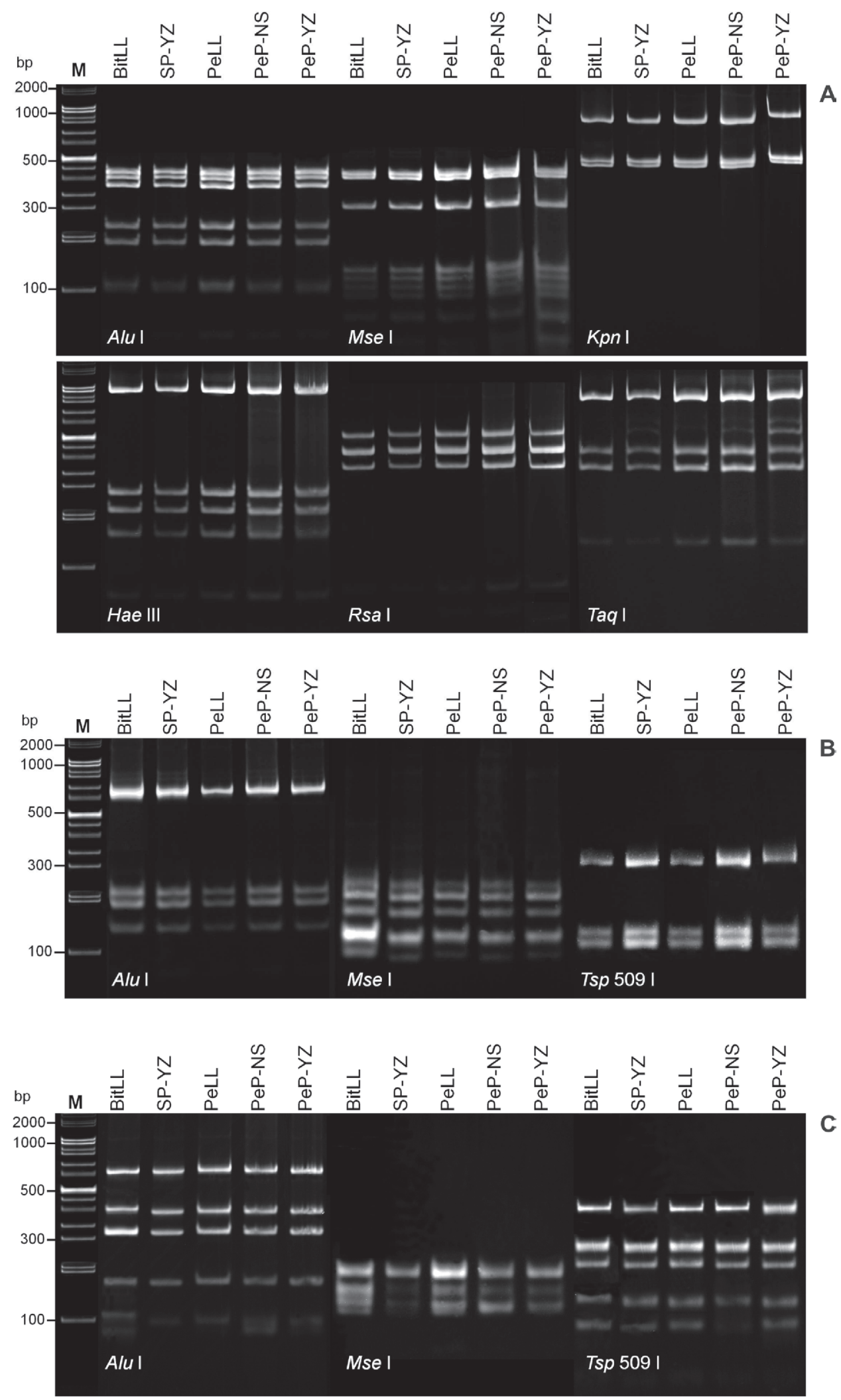

FIGURE 2 - RFLP profiles of A. 16S rRNA, B. $r p$, and C. $\sec Y$ gene sequences from bitter gourd little leave (BitLL), sesame phyllody (SP-YZ), periwinkle little leave (PeLL), periwinkle phyllodyNgwesaung (PeP-NS) and periwinkle phyllody-Yezin (PeP-YZ) phytoplasmas. DNA products were digested with 6 endonuclease enzymes (indicated in figure) and separated by electrophoresis through $8 \%$ polyacrylamide gel. Lane M: 1 kbp plus 100 bp Marker. 


$$
\begin{aligned}
& 983-\begin{array}{l}
\text { Clover phyllody (AF222065) } \\
\text { Clover phyllody (AY265217) }
\end{array} \\
& \begin{array}{|l|l}
999 & \text { Tomato big bud (AY180955) } \\
\text { Hydrangea phyllody (AY265215) } \\
\text { Chrysanthemum yellows (AY180956) }
\end{array} \\
& \text { Blueberry stunt (AY265213) } \\
& 996 \text { Leafhopper borne (AY265212) } \\
& \text { - Apricot chlorotic leaf roll (AY265211) } \\
& \text { Bitter gourd little leaf (AB741631) } \\
& \text { Periwinkle phyllody-Yezin (AB646268) } \\
& \text { Periwinkle little leaf (AB646266) } \\
& \text { Aster yellows (AY265209) } \\
& \text { Sesame phyllody (AB558132) } \\
& \text { Periwinkle phyllody -Ngwesaung (AB646267) } \\
& \text { Carrot phytoplasma (EU215426) } \\
& \text { Gladiolus witches' broom (HM590619) } \\
& \text { Plum little leaf (GU289674) } \\
& \text { Oilseed rape virescence (HM590625) } \\
& \text { Mulberry dwarf (AB693124) } \\
& \text { Ipomoea obscura witches' broom (AY265205) } \\
& \text { - Paulownia witches' broom (AY265206) } \\
& \text { Oenothera virescence (M30790) }
\end{aligned}
$$

'Ca. P. asteris'

FIGURE 3 - Phylogenetic tree constructed by neighbor-joining analysis of A. 16S rRNA, B. $r p$, and C. secY gene sequences from bitter gourd little leaf phytoplasma isolate (Bold font), four isolates of ' $C a$. P. asteris' and other 'Ca. Phytoplasma' species. Acholeplasma laidlawii (M23932, M74771 and NC_010163) were used as the outgroup of tree. The data were replicated 1,000 times and the bootstrap values $(>80 \%)$ are given at the nodes. The bar represents a phylogenetic distance. 
Bitter gourd little leaf disease associated to 'Candidatus Phytoplasma asteris'

B

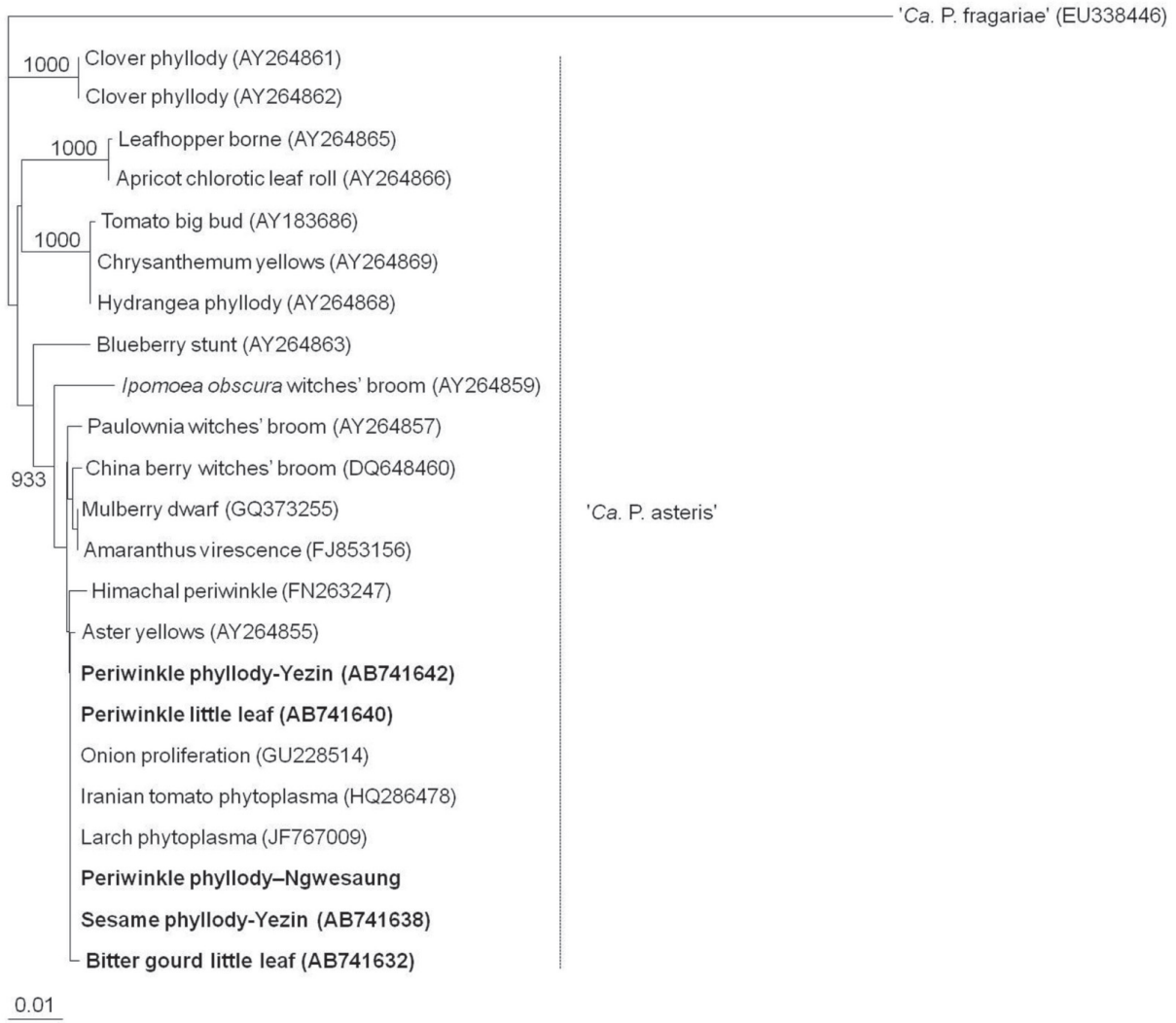

C

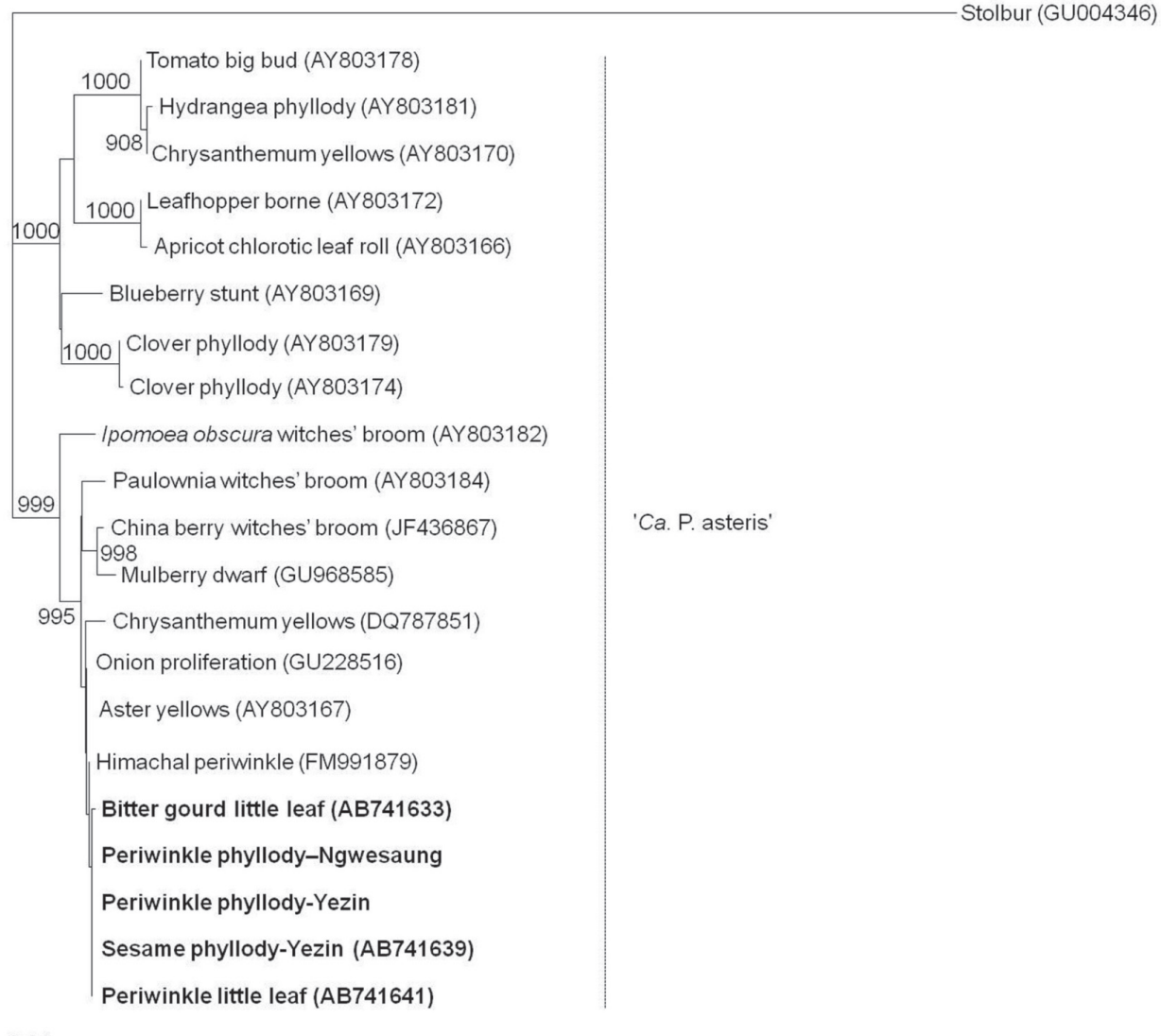

0.01

FIGURE 3 - Cont. 


\section{ACKNOWLEDGEMENTS}

This work was supported by Mid-career Researcher Program through National Research Foundation of Korea grant funded by the Ministry of Education, Science and Technolody (No.2010-0027638).

\section{REFERENCES}

Chou TG, Yang SJ, Huang PY (1976) Mycoplasmalike bodies observed in the plants of bottle gourd, chayote and balsam-pear with witches'-broom in Taiwan. Plant Disease Reporter 60:378-380

Grover JK, Yadav S, Vats V (2002) Medicinal plants of India with anti-diabetic potential. Journal of Ethnopharmacology 81:81-100.

Jung HY, Sawayanagi T, Wongkaew P, Kakizawa S, Nishigawa H, Wei W, Oshima K, Miyata SI, Ugaki M, Hibi T, Namba S (2003) 'Candidatus Phytoplasma oryzae', a novel phytoplasma taxon associated with rice yellow dwarf disease. International Journal of Systematic and Evolutionary Microbiology 53:1925-1929.

Kumar S, Singh V, Lakhanpaul S (2010) First report of 'Candidatus Phytoplasma asteris' (16SrI) associated with little leaf of cotton and luffa in India. Australasian Plant Disease Notes 5:117-119.

Lee IM, Gundersen-Rindal DE, Davis RE, Bottner KD, Marcone C, Seemüller E (2004) 'Candidatus Phytoplasma asteris', a novel phytoplasma taxon associated with aster yellows and related diseases. International Journal of Systematic and Evolutionary Microbiology 54:1037-1048.

Lee IM, Zhao Y, Bottner KD (2006) SecY gene sequence analysis for finer differentiation of diverse strains in the aster yellows phytoplasma group. Molecular and Cellular Probes 20:87-91.

Montano HG, Davis RE, Dally EL, Pimentel JP, Brioso PST (2000) Identification and phylogenetic analysis of a new phytoplasma from diseased chayote in Brazil. Plant Disease 84:429-436.

Namba S, Kato S, Iwanamis S, Oyaizu H, Shiozawa H, Tsuchizaki $\mathrm{T}$ (1993) Detection and differentiation of plant-pathogenic mycoplasmalike organism using polymerase chain reaction. Phytopathology 83:786-791.

Page RDM (1996) TREEVIEW: an application to display phylogenetic trees on personal computer. Applications in the Biosciences 12:357-358.

Palada MC, Chang LC (2003) Suggested cultural practices for bitter gourd. International operators' guide. Asian Vegetable and Development Center 3:547.

Ray RB, Raychoudhuri A, Steele R, Nerurkar P (2010) Bitter melon (Momordica charantia) extract inhibits breast cancer cell proliferation by modulating cell cycle regulatory genes and promotes apoptosis. Cancer Research 70:1925-1931.

Spoodee R, Schneider BL, Padovan AC, Gibb KS (1999) Detection and genetic relatedness of phytoplasmas associated with plant diseases in Thailand. Journal of Biochemistry, Molecular Biology and Biophysics 3:133-140.

Win NKK, Back CG, Jung HY (2011) Phyllody phytoplasma infecting sesame (Sesamum indicum) in Myanmar. Tropical Plant Pathology 35:310-313.

Win NKK, Jung HY (2012) The distribution of phytoplasmas in Myanmar. Journal of Phytopathology 160:139-145. 